\title{
Entrepreneurship from an Islamic Perspective
}

\author{
Ali Aslan Gümüsay \\ Saïd Business School, University of Oxford \\ Park End St, Oxford, OX11HP, United Kingdom \\ Ali.Gumusay@sbs.ox.ac.uk
}

Forthcoming in Journal of Business Ethics

The original publication is available at

http://ink.springer.com/article/10.1007/s10551-014-2223-7

Keywords: Entrepreneurship, Religion, Business Ethics, Social Entrepreneurship, Islam

Acknowledgements: My sincere thanks to the associate editor Domenec Mele and the anonymous reviewers for their very valuable comments on the manuscript. I would also like to acknowledge the insightful feedback and suggestions received on earlier versions of this work from Talal Al-Azem, Sue Dopson, Pegram Harrison, Fahri Karakas, Tim Morris, Michael Smets and Marc Ventresca and the support of the Novak Druce Centre for Professional Service Firms at the Saïd Business School, University of Oxford. 


\title{
Entrepreneurship from an Islamic Perspective
}

\begin{abstract}
Research about the role of religion in entrepreneurship and more broadly management is sparse. In this conceptual article we complement existing entrepreneurship theory by examining entrepreneurship from an Islamic perspective (EIP). EIP is based on three interconnected pillars: the entrepreneurial, socio-economic/ethical and religio-spiritual. We outline how Islam shapes entrepreneurship at the micro-, meso- and macro-level, indicate how Islam may be considered an entrepreneurial religion in the sense that it enables and encourages entrepreneurial activity, review research streams interlinking Islam with entrepreneurship and management and outline promising research approaches.
\end{abstract}

And when the prayer is ended, then disperse in the land and seek of Allah's favor, and remember Allah much, that you may succeed. (Quran 62:10).

He it is who has made the earth subservient to you, so walk in the paths of it and eat of His provision. And to Him will be the resurrection. (Quran 67:15)

The Prophet Muhammad (peace be upon him) was asked what type of earning was best, and he replied: "A man's work with his hands and every (lawful) business transaction." (Al-

Tirmidhi)

\section{Introduction}

Research about the role of religion in entrepreneurship and more broadly management is sparse. Religion is like an elephant in the room: impossible to overlook, yet largely ignored. While entrepreneurial activities have inter alia been researched from economic (Casson, 2003), institutional (Battilana, Leca and Boxenbaum, 2009), political (Schneider and Teske, 1992), psychological (Begley and Boyd, 1987) and social (Shapero and Sokol, 1982) perspectives, religion has been largely neglected with very few exceptions (Dana, 2010). A religious perspective on entrepreneurship is distinct, as it commonly entails specific and detailed narratives and practices, a defined scriptural source and a distinct meta-physical 
objective. A holistic approach to entrepreneurship research which incorporates religion may hence complement and enrich existing entrepreneurship theory and practice.

Habermas (2001) argues that we are in a post-secular society. Contrary to the conventional understanding of modernity as secular, religion continues to have a major role in society. Berger (1999, p. 2), formerly an advocate of secularization theory has shifted his view: "The world today, with some exceptions $[\ldots]$ is as furiously religious as it ever was, and in some places more so than ever. This means that a whole body of literature by historians and social scientists loosely labeled 'secularization theory' is essentially mistaken."

We may not exclude religion from our research attempting to analyze a secular social science, when the social is not secular. The study of science as a social activity through the sociology of scientific knowledge (Berger and Luckmann, 1966; Bloor, 1976; Kuhn, 1962) positioned science within a sociological realm. Science-related research is a social activity and management as a social science is research by, about and for people. As some of those people are religious, entrepreneurship specifically and management research and practice more generally need to integrate the meta-physical.

With 1.6 billion adherents constituting $23 \%$ of the world population, Islam is the world's second largest religion expected to grow to 2.3 billion or $26.4 \%$ of the world's population by 2030 (Pew Research Centre, 2011). For many Muslims, religion has an important role in their life (Pew Research Centre, 2012). In recent years various conferences such as the World Islamic Economic Forum or the Global Islamic Economy Summit concentrated on and thus raised awareness of the intersection of Islam and the economy. The market of Muslim customers is rising and entrepreneurs are developing (new) products to respond to demand. Given these trends, a reflection on the interaction between Islam and entrepreneurship becomes particularly pertinent. 
The outline of this article is as follows: First, we critically reflect on the concept and conceptualization of entrepreneurship from an Islamic perspective (EIP). Second, we concentrate on how Islam shapes entrepreneurship at the micro-, meso- and macro-level of analysis. Third, we contemplate on Islam as an entrepreneurial religion. Fourth, we reflect on the thin literature on EIP. Fifth, we engage EIP with Management theories suggesting to connect it to the manifold core of research. Sixth, we contemplate on the future of EIP and finally conclude.

\section{Entrepreneurship from an Islamic Perspective}

Entrepreneurship from an Islamic perspective is a composition of two individually contested concepts: Islam and entrepreneurship. Islamic in its minimal core is the declaration of belief in the one God and that Muhammad (peace be upon him, pbuh) is the messenger of God. In a famous Hadith narrated by Al-Bukhari the prophet is asked by the archangel Gabriel about Islam, Iman and Ihsan and explains that Islam is the testimony that there is no God but Allah, that Muhammad is His messenger, to perform prayers, to pay Zakat, to fast in Ramadan and to make the pilgrimage if able to do so. Iman is the belief in Allah, His angels, His books, His messengers, the Last Day and divine destiny. Ihsan is to worship Allah as if you see Him, while not seeing Him, although He sees you. The attribute of Islamic in EIP is linked to this belief and submission to God.

The word entrepreneurship is derived from the French entreprendre and the German unternehmen. Both verbs translate to "undertake". In a way, the entrepreneur undertakes endeavors that others do not. The entrepreneur "is at once one of the most intriguing and one of the most elusive in the cast of characters that constitutes the subject of economic analysis" (Baumol 1993, p. 2). Hébert and Link (1989) condense the taxonomy of economic theories on 
entrepreneurship into three key intellectual traditions - the Austrian, Chicago and German school. The proponents of the so-called Austrian school like Kirzner (1973; 1979) advocate that entrepreneurs exploit opportunities. The Chicago school (Knight, 1921) stresses the importance of risk-taking and the bearing of uncertainty. The German school, particularly known through the works of Schumpeter (1934), concentrates on the role of new combinations and creative destruction. A summary definition may be that an entrepreneur is someone who exploits opportunities often through the recombination of existing resources whilst bearing the uncertainty in the undertaking.

EIP is more than a simple summation of Islam and entrepreneurship. It is based on three interwoven pillars. The first pillar, based on the definition of entrepreneurship, is the pursuit of opportunities. The second pillar is socio-economic or ethical. Effectively, EIP is guided by a set of norms, values and recommendations. The third pillar is religio-spiritual and links people to God with the ultimate objective of pleasing Allah. These pillars are interlinked. Pillars two and three are not simply added. All three pillars shape each other. Furthermore, these pillars have specific scriptural sources as well as institutions and processes of interpretation. EIP thus contains its own methodology of approaching its understanding. It needs to be comprehended and analysed holistically containing entrepreneurial pursuit, religiously-shaped values, concrete Islamic obligations, community-influence, scriptural sources and an ecosystem of actors and institutions which provide an interpretation for this religio-spiritual lens.

Sometimes EIP is compared to and positioned against an unethical Western entrepreneurship. In response, one may say that entrepreneurship itself but especially social or cultural entrepreneurship is ethical, potentially combining the entrepreneurial and ethical pillars mentioned above. To allow for analysis, comparison and integration, specific Western 
measures of ethics and social responsibility (recently Roulet and Touboul, 2014) could be better connected to the intrinsic ethical objectives embedded in Islamic religious tenets.

Social entrepreneurship has received much recent research attention (Dacin, Dacin and Tracey, 2011; Nichols, 2006; Pless, 2012) institutionally manifested through newly established research centers such as the Skoll Centre, research programs and courses on social entrepreneurship. The definition of social entrepreneurship generally evolves around the combination of entrepreneurship and a social mission (Mair and Marti, 2006). Austin, Stevenson and Wei-Skillern (2006, p. 1) define social entrepreneurship as "entrepreneurial activity embedded with a social purpose." Some scholars have also focused on the intersection of ethics and entrepreneurship (Harris, Sapienza and Bowie, 2009; Wempe, 2005). Yet, ethical, social and cultural entrepreneurship do neither have a religio-spiritual pillar nor religious scriptural sources on which the ethical foundation as well as concrete processes are based. EIP is thus not simply an ethical approach to entrepreneurship, although it incorporates ethical values and Islamic ethics are applied to the economy (Ramadan, 2009). It is rather distinct from ethical, social or cultural entrepreneurship, as it entails specific practices, scriptural sources as well as a meta-physical objective and relationship to God.

EIP may falsely be considered entrepreneurship in Muslim-majority countries or entrepreneurship for Muslims. While there is an institutional component to facilitate EIP and entrepreneurship in general, the country does not have to be a Muslim-majority country. The products and services also do not have to focus on Muslims. The entrepreneur or at least a part of the organization has to be Muslim to practice EIP, as EIP contains the religio-spiritual lens. While the practice of any entrepreneur may be in accordance with Islamic values, EIP also contains a belief in and practice for God which presupposes some form of religiosity.

This does not imply that EIP provides no insights for Non-Muslims. On the contrary, EIP provides an approach to critically reflect on entrepreneurship, e.g. by shifting the focus from 
individual entrepreneurship based on the pursuit of self-interest to family or community entrepreneurship. The practices of EIP may be adopted, values regarded as inspiration and certain beliefs may be substituted. EIP may and should allow us to reflect more broadly on the role of religion in entrepreneurship and how both a specific scriptural source as well as a meta-physical being provides guidance and recommendation. Furthermore, insights into EIP may help to engage better with religious entrepreneurs.

Yet, EIP has not re-engaged with the entrepreneurship literature but has rather concentrated on adopting and adapting entrepreneurship for Muslim-majority countries. This development of an Islamic lens on economics, business and finance is very much linked to the Islamization of knowledge movement in the 1970s and 1980s, particularly through the International Institute for Islamic Thought. The underlying assumption was that much research and thought has a theoretical and empirical focus on the West and may not be applicable to other parts of the world. Concepts such as Islamic economics (Chapra, 1992, 2000; Naqvi, 1994; Siddiqi, 1981) and Islamic finance (Usmani, 2001; Zaher and Hassan, 2001) provided a contextualized lens and became part of a strong value-based development agenda. Scholars of EIP need to reconnect with both academic and religious sources to rethink and reflect on the future of EIP and to make it more relevant for entrepreneurship theory and practice in general.

We also need to reconsider the terminology and critically reflect on its genesis. Islamic entrepreneurship has become the established term similar to Islamic economics and Islamic finance to describe an Islam-based approach towards certain business and finance practices. A more correct formulation may be entrepreneurship from an Islamic perspective. Islam arguably does not offer a concrete theory of entrepreneurship - nor finance or economics but rather a foundation and framework to develop a plurality of models of finance, economics and entrepreneurship. In that sense, it is rather a perspective or grounding. Islamic entrepreneurship as well as Islamic finance and economics may thus be misleading terms. To 
come from the scriptures through their interpretation to a religious conceptualization of entrepreneurship is an intense and complex process. Entrepreneurship, economics and finance from an Islamic perspective may be more accurate expressions.

However, Islamic entrepreneurship clearly is more memorable and easier to use in marketing. Islamic entrepreneurship appears to be a marketing-based construct rather than an academically rigorous and theologically appropriate one. We will thus need a reflectivecritical engagement with the term - with both caution and a critical understanding and discourse of what it is and what it is not. At least in the academic context we would suggest to use the alternative and more accurate terminology of entrepreneurship from an Islamic perspective.

\section{An Islamic Role in Entrepreneurship}

The role of Islam in entrepreneurship is based on the interlinkage between the textual sources and contextual setting. The primary sources are the Quran and Sunnah. For Muslims the Quran contains the words of God in 114 surahs (chapters) with over 6000 àyāt (verses; singular: āyah) gradually revealed over a period of 23 years around 600 AD. The Sunnah is the deeds, sayings and silent or tacit approvals of the prophet Muhammad (pbuh). Secondary sources and practices are Ijma' (Consensus) and Qiyās (Analogy). Ijma' is the unanimous agreement amongst a certain group of people like religious scholars or the entire Muslim community depending on the Madhhab, that is the specific school of jurisprudence. Qiyās is a form of analogical reasoning, somewhat contested amongst scholars. For some scholars, there exist potentially certain tertiary sources such as the value of public good.

These sources may affect extensively the various levels of entrepreneurship shaping the entrepreneur, the organization and its immediate and wider ecosystem. At the micro-level, the 
individual entrepreneur may be motivated by religion (Audretsch and Bönte, 2007) with a distinct entrepreneurial pursuit potentially as someone who may be termed a homo islamicus in contrast to the homo economicus. For such an entrepreneur, success is not defined simply by material reward, although business success is an integral part, but also a socio-economic and metaphysical achievement - which is both in this world as well as in the hereafter. This achievement is sometimes termed falah, implying a state of both material and spiritual wellbeing (Beekun, 1996, p. 1).

The entrepreneur is not only affected by embedding work in his religious life of inter alia praying and fasting but rather in all kinds of activities. He sees work as a religious duty, a form of 'wor(k)ship' to seek Allah's bounty as mentioned in the Quran in chapter 62 verse 10. His worldview may change fundamental concepts such as a different understanding of risk, with God as protector, or work, with a threefold reward structure of material, socio-economic and spiritual gains. Actions are shaped by both socio-economic considerations to wider society and ethical considerations in the employer-employee relationship and the interaction with business partners. The Quran states for example: "O you who believe! Do not devour your property among yourselves wrongly; but trade by mutual consent...” (Quran, 4.29). In a Hadith the prophet Muhammad (pbuh) said: "None of you is of complete imān until he loves for his brother what he loves for himself" (Bukhari, Muslim). In another Hadith he mentioned: "Give the worker his wages before his sweat dries" (Tirmidhi; Ibn Majah). In chapter 11 verse 85 God gives explicit guidelines on trade such as giving just measure and weight. Nature is mentioned manifold times in the Quran and various Hadiths advocate what may be summarized as sustainable practices towards animals and the environment. One Hadith mentions how the prophet saw Sa'd ibn Abi Waqqas taking ablution and said to him: "O Sa'd, how wasteful you are!" Sa'd asked if water could be wasted in taking one's ritual ablution. The prophet responded: "Yes, even if you are using the running water of a river" 
(Ahmad). In another Hadith (Al-Bukhari, Muslim) the prophet tells a story of how Allah rewarded a man and forgave him his sins because the man climbed down a well, filled his shoe with water and holding his shoe between his teeth climbed up again to give a very thirsty dog to drink some water.

In EIP final ownership lies with Allah (Quran 24:33) with humans as caliphs, trustees or viceregents (Quran 2:30; 57:7). Even immediate ownership is not with the entrepreneurs. Not only is hoarding of wealth prohibited (Quran 3:180; 9:34) they also need to purify their wealth by giving Zakat (Quran 9: 103), as there is a right for the beggar and the deprived in their wealth (Quran 51:19). Wealth entails obligations. Zakat must be paid each year by morally-responsible Muslims who possess the zakatable minimum (Nisāb) beyond immediate needs and debts. The Zakat rate for most goods and assets is $2.5 \%$. Muslims believe that this giving does not decrease but increase wealth as the prophet stated "Sadaqah does not reduce property”(Muslim).

At the meso-level, Islam shapes the organization in multiple ways, as all areas of a business such as strategy, organization, human resources, finance, marketing are impacted by an Islamic perspective. The strategy is expected to be not only profitable but also in line with worldly socio-economic welfare as well as spiritual growth. Certain products such as pork (Quran 2:173), alcohol or gambling (Quran 5:90) are forbidden. Certain practices such as false measuring (Quran 55:9; 17:35) or lying (Quran 6:152; 33:70; 17:36) are not allowed and others such as fulfilling contracts are obligatory (Quran 5:1). Religious activities like the five daily prayers or fasting may shape the organization e.g. through a prayer room, specific working hours during Ramadan or festivals.

The financial side of the business is very relevant for entrepreneurship. Islam denominates specific prohibition in the financing and investment of a business activity. In a four steps 
process Allah gradually emphasized that riba, the taking of interest, is forbidden. In a first verse (Quran 30:39) God stated "That which you give in usury [riba] in order that it may increase on people's property has no increase with Allah...” The second verse (4:161) says: "And (because) of their taking usury when they were forbidden it..." In the third revelation (3:130): "O you who believe do not live on usury, multiplying your interest many times over..." Finally, verse 2:275 established that: “...Allah has permitted trade and forbidden usury..." The Quran even entails a declaration of war against those who use usury (Quran 2:279). Other prohibitions are gharar and maisir/qimār. Gharar refers to the uncertainty or ambiguity due to the lack of clarity on the price or subject matter in an exchange or contract. Maisir or qimār relates to games of chance such as gambling.

Islam encourages certain (entrepreneurial) financial partnerships such as Mudārabah and Mushārakah. In a Mudārabah partnership one party, the rabb-ul-māl, provides capital and the other, the mudārib; entrepreneurial labour. In a Mushārakah the various parties provide capital and some also engage in the management side. Financial loss is borne by the capital provider in proportion to financial contributions, while the entrepreneur effectively loses time and effort invested in the project. Profits are shared according to pre-agreed ratios.

A relatively new form to provide financial services is called microfinance. Microfinance is the provision of financial services such as small loans to rather poor micro-entrepreneurs (Armendariz de Aghion and Morduch, 2005; Khavul, 2010). A key feature is group lending to jointly-liable clients and the involvement of the borrower's local community. Linked to the microcredit movement microfinance developed particularly from the 1970s onwards in Asia and Latin America. It became increasingly popular within the last decade and is reaching over 200 million people as of December 31, 2010 of whom over $80 \%$ are women (Maes and Reed, 2012). Muhamad Yunus, founder of the Grameen Bank Bangladesh, won the Nobel Peace Prize for developing and pioneering microfinance to foster economic and social development. 
Microfinance, however, is based on loans financed by interest rates and scholars and practitioners have endeavored into an approach to Microfinance from an Islamic perspective. Islamic Microfinance has certain distinct characteristics vis-à-vis conventional microfinance such as Islamic financial instruments, targeting families and incorporating religious work incentives (Abdul Rahman, 2007; Ahmed, 2002). It may thus modify within religious boundaries the provision of financial capital particularly targeting Muslim microentrepreneurs.

At the macro-level Islam affects a variety of institutions like the state and market. The specific roles of these institutions from an Islamic perspective are subject to academic debate with a long history of scholarly engagement (El-Ashker and Wilson, 2006). Islamic economic thought developed in the last 1400 years through various phases or waves by scholars such as Abu-Yusuf, Mawardi, Ghazali, Ibn Taimiyyah, Ibn Khaldun, Shah Wali Allah, Muhammad Iqbal, Muhammad Baqir Al-Sadr, Chapra and Siddiqi (Siddiqi, 1992). Islam provides extensive guidelines for an economic system and regulatory framework through the creation of offices such as the Hisbah, a form of ombudsman who supervises the market, as well as certain legal and ethical implications such as inheritance or welfare regulations. Potentially an Islamic economy is "defined within the parameters of its own ethical system" (Naqvi, 1994, p. 80). The state and the market thus shape the institutional ecosystem of entrepreneurship.

\section{Islam as an Entrepreneurial Religion}

Islam itself may be considered an "entrepreneurial religion" (Kayed and Hassan, 2010) in the sense that it enables and encourages entrepreneurial activity, i.e. opportunity pursuit, risktaking and innovation. Both the Quran and Sunnah emphasize the pursuit in this world. In verse 77 of chapter 28, it reads "But seek the abode of the Hereafter in that which Allah has 
given you, and forget not your portion of the world, and be kind even as Allah has been kind to you, and seek not corruption in the earth; for Allah loves not corrupters." The prophet stated: "Work for your worldly life as if you were going to live forever, but work for the life to come as if you were going to die tomorrow" (considered a weak Hadith). A saying of the prophet narrated by Ahmad, effectively endorsing both entrepreneurial and sustainable practice, recommends: "Even when the day of judgement approaches, if anyone has a plant in hand, he should quickly plant it."

When the term 'entrepreneur' had been introduced to economic theory by the Irish economist of French descent Richard Cantillon ([1755], 1931) he perceived an entrepreneur as a specialist in risk taking. While the worker has an insured wage, the entrepreneur incurs a profit or a loss at the end of the business activity. The concept of risk is closely related to the concept of rizq (sustenance or wealth) - not only in its orthography. For a Muslim, rizq ultimately is granted by Allah. An entrepreneur thus needs to have tawakkul, trust in Allah. In that sense, risk is 'outstored' and risk taking is made easier. On the financial site, it is even a form of obligation due to the prohibition of interest. Wealth itself is not allowed to generate wealth. Investment must be linked to risk and the investor becomes an entrepreneur himself and helps entrepreneurs through investing in their business endeavors.

Yet "[i]n the dominant academic discourse on entrepreneurship, Islam has been negatively related to successful entrepreneurship" (Essers and Benschop, 2009, p. 408). Regulations shaped by Islam are made partially responsible for less economic development. Kuran (1989, 1996, 2012) argues that certain Islamic legal institutions had an inhibitive character to development. Ul-Haq and Westwood (2012, p. 244) state that "[t]his work repeats familiar orientalist topes and implied binaries related to stagnation, backwardness, lack of civic society, lack of truth, dysfunctional values and failure to modernize." For Kayed and Hassan (2010, pp. 8-12) Westernisation is somewhat conceived as a must for modernization. Scholars 
such as Rodinson (1974) argue that Islam is not impeding economic activity. Empirical data on Muslim practice both in terms of fatawa rulings and entrepreneurial practices may suggest otherwise. This, of course, has a category bias, as it would attribute to Islam what may also be attributed to culture, geography or politics. Rather what halted development according to Turner (1984) are the four missings: the middle class, city states, political freedom and revolution.

An often misread Hadith is sometimes mentioned to indicate the discouragement of innovation and entrepreneurship. The Hadith narrated by Abu Dawud and at-Tirmidhi states that every innovation (bid'ah) is misguidance. What is meant in this Hadith is a divergence from the scripture and religious matters, as this is considered to have happened with other religions, rather than innovation in business activities. More broadly a distinction between good or praiseworthy bid'ah and bad or blameworthy bid'ah is made by Imam Al-Shāfi ' $\overline{1}$ and others and innovation classified along the five categories of Muslim law (ạ̣kām): necessary, recommended, permitted, disapproved and forbidden innovation.

It is important to note, that a religion is per definition based on a certain inalienable core and proposes certain immutable practices and values. The question is less, whether this is the case, but to what extent and whether there are processes which allow change and innovation to be incorporated into the religion. The process of Ijtihad serves to distinguish between good and bad innovations. Ijtihad incorporates both text and context and allows for "entrepreneurial" interaction. A closure of the doors of Ijtihad would then create some form of inertia. Islamic regulations are theoretically not static but may rather both in its content as well as process be termed entrepreneurial or entrepreneurship enabling and encouraging. 


\section{Management Theory and EIP}

Management research has benefited from incorporating a variety of disciplines into its research agenda. Scholars developed insightful theories building on economics (Williamson, 1985), psychology (Weick, 1979), ecology (Hannan and Freeman, 1977) and sociology (Selznick, 1949; Meyer and Rowan, 1977 and DiMaggio and Powell, 1983) to name a few. Management exhibits fluid boundaries. It sometimes transcends boundaries. The combination of theology and religion studies with management may very well add to these enriching interdisciplinary approaches. Given the size of the global Muslim population and the scholarly neglect an engagement with Islam and management is particularly important.

While religion has a profound impact on contemporary societies, management researchers surprisingly have not engaged more comprehensively with the interrelationships between religion and management (King Jr., 2008) or religion and organization (Tracey, 2012, ChanSerafin, Brief and George, 2013). Religion has not substantially entered the management research agenda. When scholars have researched the role of religion in business, religion was primarily considered from a marketing (Rinallo, Scott and MacLaran, 2013; Temporal, 2011) best practice, work and ethics perspective (Gundolf and Filser, 2013). Institutionally, at the Academy of Management, a Special Interest group "Management, Spirituality, and Religion" has formed, but it is just over a decade old and not yet a division.

The disregard may very well stem from the sensitivity of the concept of religion in the business sphere. The closest some scholars tackle religion-linked phenomena is through the concept of spirituality which has produced a growing body of literature (Karakas, 2010; Mitroff and Denton, 1999; Neck and Milliman, 1994; Steingard, 2005). King Jr. (2008, p. 220) points out that researchers are encouraged towards spirituality and away from religion. According to Ashforth and Pratt (2003) spirituality comprises of transcendence of the self, 
holism and harmony and growth. As this definition shows, spirituality does not cover the role of more organized belief and value constellations.

The sociology of religion literature provides a research stream which could be linked to management research. This stream offers foundational analysis on beliefs, practices and organizational forms of religion, albeit largely neglecting scholars inter alia of the so-called Golden Age of Islam such as Ibn Khaldun. It also contains what is classified as Orientalist tendencies and biases (Said, 1978; Turner, 1978). Weber (1904-1905/1965) saw Islam as an obstacle to capitalist development and also accentuated the idea that each religion associates with a primary status group which shapes societal culture. The literature is hence in need of critical engagement.

Nonetheless, in its core the sociology of religion literature provides rich insights for an intellectual engagement between business, economics, entrepreneurship and religion. Within this literature, classical sociological scholars retain a prominent role. Marx (1843/1972) emphasized the interlinkage of religion and economics and that religion masks capitalist exploitation. Weber (1904-5/1965) noticed that the protestant ethic formed a capitalist spirit, which was driven by a notion of calling and the belief that hard work, discipline and integrity may lead to salvation. Durkheim (1912/1995) identified four core features of religion, namely that it is a collective phenomenon, comprises of beliefs and practices, is not magic and distinguishes between the sacred and the profane. A critical engagement with the sociology of religion literature and the integration of an Islamic perspective may offer new insights. The aforementioned concept of 'wor(k)ship', for example, illustrates that the relationship between the sacred and profane is not a simple dichotomy, but may be rather much more complex and intertwined.

Research on Islam and management in general as well as EIP in particular is thin, peripheral and negatively connotated. Ul-Haq and Westwood (2012, p. 229) assert: "Islamic 
management and organization knowledge (MOK) is relatively under- and mis-represented in the literature." Research on Islamic management and EIP is almost absent from mainstream management journals. Scholarly work focuses primarily on Islamic Business Ethics or Islamic work ethics (Arslan, 2001; Possumah, Ismail and Shahimi, 2013; Rice, 1999; Uygur, 2009; Yousef; 2001). Tracey (2012) notes: "At the core of this work [on religion and business ethics] is the question of whether people who hold religious beliefs are more or less likely to behave ethically than people who do not hold such beliefs. As one might expect, there is evidence to support both positions." Fewer scholars have concentrated on other topics related to management such as Islam and business (Wilson, 2006) or Islam and leadership (Beekun and Badawi, 1999).

There is a significant amount of research on religious organizations in social psychology and sociology (Greil and Davidmann, 2007; Ysseldyk, Matheson, and Anisman, 2010). Yet the role of religious identity in and between secular business organizations remains underresearched. Religion is an integral part for many entrepreneurs as well as their organization and its ecosystem. Few scholars have empirically engaged with the intersection of Islam and entrepreneurship (Adas, 2006; Basu and Altinay, 2002; Kayed and Hassan, 2010; Roomi and Harrison, 2010; Sloane, 1999). Yet the meta-physical in the social sciences becomes for the researcher at least a social fact, when the actors belief in and act according to it. We need to integrate religion into the research agenda and particularly EIP needs further attention, as there are many Muslim entrepreneurs who actively seek to incorporate their religious beliefs with their business activities and both merit empirical analysis and scholarly engagement. 


\section{Future Research on EIP}

Religion does not only affect ethics and values, but the whole political, economic, social, legal and environmental sphere. While much research in the neoclassical tradition, has an undersocialised view of human action (Granovetter, 1985), we need not only incorporate the broad range of linkages in our research, but also broaden or add to the concept of social itself. Human action is not only social, it is spiritual/religious, too. Religion as a social phenomenon means that a spiritual/religious relationship to God shapes social practices. The social sciences of management and entrepreneurship research will have to take into account the religiosity of actors. EIP research hence requires analysis of the entrepreneurial, socioeconomic/ethical and religio-spiritual pillars and their interactions.

The inclusion of the religio-spiritual pillar may also help us to reflect on the conceptualization of the entrepreneur and actors more generally as complex beings of heart/soul, body and mind (Guemuesay, 2012). Activity has an intra-actor component and a multifaceted actorenvironment interaction. Some contemporary Islamic philosophy thinkers such as Muhammad Iqbal, Fazlur Rahman or Naquib Al-Attas have very much emphasized the physical, intellectual and spiritual human development. This understanding of a human being allows for a different approach towards the identity, role and activity of the entrepreneur away from a simplistic homo economicus concept. The religio-spiritual is a factor both in the individual and social realm which lacks research attention.

As EIP delves into an area between religion and business, future engagement with EIP requires collaborative and interdisciplinary research designs and projects. Economists, sociologists, management and business academics need to seek cooperation with theologians and scholars of religions to enable a co-production of knowledge through a collaborative 
research processes and outcomes. This is a challenging endeavor which requires crossing disciplinary boundaries and building bridges where fragmented, loose or no interaction exists in terms of communication, institutional linkages or research outlets.

There are various relevant research streams which may link with EIP. National Innovation Systems (Freeman, 1995; Lundvall, 1992) could particularly focus on the development role of EIP (Kayed and Hassan, 2010). Economic theories may wish to reflect on concepts such as satisficing or moral hazard and the role of religion on information asymmetry and human interest. Religion can offer an interesting resource in the Resource-Based View of the firm (Barney, 1991) and a component when considering sensemaking (Weick, 1993) or organizational identity (Albert and Whetten, 1985). From a strategy perspective, religious obligations may be perceived as additional constraints to organizations possibly becoming a competitive disadvantage. On the other hand, there may be potential benefits such as a religious community (Dodd and Gotsis, 2007; Dodd and Seaman, 1998). Finally, entrepreneurs and managers may actually not judge themselves on their profit-maximisation ability through their competitive advantage, but rather on some form of rizq (sustenance) increase. Such strategy in practice would be very different from much strategy textbook readings.

A very promising endeavor for EIP and more generally religion and management is NeoInstitutional Theory. Religion, both as a social as well as a metaphysical phenomenon, has much to contribute to concepts such as legitimacy and meaning. Friedland and Alford (1991) introduced an interinstitutional system consisting of five institutional logics, namely the capitalist market, bureaucratic state, democracy, nuclear family, and Christian religion. Building on Friedland and Alford (1991) as well as Jackall (1988) Thornton and Ocasio (1999, p. 804) defined institutional logics "as the socially constructed, historical pattern of material practices, assumptions, values, beliefs, and rules by which individuals produce and 
reproduce their material subsistence, organize time and space, and provide meaning to their social reality." Organizations face a multiplicity of institutional logics (Greenwood, Diaz, Li and Lorente, 2010) and select from a repertoire of organizational responses (Oliver, 1991; Pache and Santos, 2010). This leads to institutional complexity which Greenwood, Raynard, Kodeih, Micelotta and Lounsbury (2011) define as "situations where organizations experience a multiplexity of different pressures from a plurality of institutional logics" (p. 357), and possibly (practice-driven) institutional change (Smets, Morris and Greenwood, 2012). In this interinstitutional system, religion is (already) a key component - albeit very much neglected. The impact of religion is interdependent of its exchange with other logics, the field, organizational attributes and the resulting responses as well as the recurrent constant reconsiderations of these incidents. The role of religion needs to be considered within this web of relationships. Scholars on Islam and management as well as EIP may enrich our understanding of the role of religion through a neo-institutional lens.

Both religion and entrepreneurship are dynamic concepts. The theory and practice of EIP is thus manifold dynamic. EIP research needs to advance and integrate advances in both scholarly work on religion as well as entrepreneurship and not try to Islamize knowledge at a certain point in time. Similarly, entrepreneurship research needs to take religion seriously. Religion matters in practice - it should also in theory. Theologians advance and contextualize our understanding of Islam through reason (aql) and transmission (naql). Entrepreneurship scholars similarly contextualize and advance our understanding of entrepreneurship. EIP needs to include progress in both fields and proceed as an approach in itself whilst at the same time feeding back into the individual fields. 


\section{Conclusion}

The role of religion on business is becoming quite prevalent in our post-secular society. The metaphysical is becoming a social truth and scholars should not shy away from it, but rather consider it as an important phenomenon in both management research and practice. EIP is a complex and contested concept based on three interlinking pillars: the entrepreneurial, socioeconomic/ethical and religio-spiritual. It is distinct from ethical entrepreneurship, as it entails defined practices and scriptural sources as well as a distinct meta-physical objective. As the specifics of EIP have to be drawn and interpreted from the scriptures and applied to context, we prefer to refer to entrepreneurship from an Islamic perspective, although common usage and practical marketing interest favor the constellation of Islamic entrepreneurship.

EIP affects the micro-, meso- and macro-levels of analysis in multifaceted ways by shaping the individual, the organization and the variety of institutions such as the states and markets. This complexity needs to be incorporated into holistic models which yield explanatory richness whilst not neglecting the value of parsimony. In fact, Islam itself may be analysed in terms of its entrepreneurial character. Both its interpretative processes and content may be called entrepreneurial. Ijtihad allows critical reasoning and contextualization. The emphasis on hard working and the prohibition of interest, for example, strengthen entrepreneurial pursuits.

As EIP is growing both empirically and intellectually it requires much more scholarly engagement. Islam is very much under- and somewhat mis-represented in the literature. Research on EIP is thin and peripheral and needs to be incorporated into mainstream management and entrepreneurship research by inter alia linking it to strategy, human resources, finances and organizational theories. While research on EIP is sometimes very recommendatory and value-judgement is important, we nonetheless need to be methodologically rigorous and separate description from prescription. Rather than Islamizing 
some kind of Western knowledge, knowledge needs to be critically contextualized. In this process, EIP is not simply a peripheral phenomenon but a core activity within the global entrepreneurial landscape. It is also not a static but rather a multiple-dynamic concept transforming as context changes, our understanding of entrepreneurship progresses and the interpretation of scriptural sources advances. EIP is in need of interdisciplinary research $-\mathrm{a}$ very entrepreneurial pursuit indeed. 


\section{References}

Adas, E.B. (2006). The Making of Entrepreneurial Islam and the Islamic Spirit of Capitalism. Journal for Cultural Research 10(2): 113-137.

Ahmad, Habib (2002). "Financing micro enterprises: an analytical study of Islamic microfinance institutions." Islamic Economic Studies 9.2: 27-64.

Albert, S. and Whetten, D. (1985) Organizational Identity, in in Hatch, M.J. and Schultz, M. (Eds.) Organizational identity: a reader, pp. 89-118 (Oxford: Oxford University Press, 2004).

Austin, J., Stevenson, H. and Wei-Skillern, J. (2006). Social and commercial entrepreneurship: Same, different, or both? Entrepreneurship: Theory \& Practice, $30(1), 1-22$.

Armendariz de Aghion, B.A. and Morduch, J. (2005). The Economics of Microfinance. (Cambridge, Mass.: MIT Press).

Arslan, M. (2001). The work ethic values of Protestant British, Catholic Irish and Muslim Turkish managers. Journal of Business Ethics 31(4): 321-339.

Ashforth, B.E. and Pratt, M.G. (2003). Institutionalized spirituality: An oxymoron? In Giacalone, R.A. and Jurkiewicz, C.L. (Eds.), The handbook of workplace spirituality and organizational performance, pp. 93-107. (Armonk, NY: M.E. Sharpe).

Audretsch, D. B. and Bönte, W. (2007). Religion and Entrepreneurship. CEPR Discussion paper No. 6378.

Barney, J. B. (1991). Firm resources and sustained competitive advantage. Journal of Management 17(1): 99-120.

Battilana, J., Leca, B. and Boxenbaum, E. (2009). How Actors Change Institutions: Towards a Theory of Institutional Entrepreneurship. The Academy of Management Annals 3(1): 65-107.

Basu, A. and Altinay, E. (2002). The interaction between culture and entrepreneurship in London's immigrant businesses. International Small Business Journal 20(4): 371-393.

Baumol, W. (1993). Entrepreneurship, Management, and the Structure of Payoffs. (Cambridge, Mass.: MIT Press).

Beekun, R. I. (1996). Islam and business ethics. (Herndon, VA: International Institute of Islamic Thought).

Beekun, R. I. and Badawi, J. (1999). Leadership: An Islamic Perspective. (Beltsville: Amana Publications). 
Begley, T. M. and Boyd, D. B. (1987). Psychological characteristics associated with performance in entrepreneurial firms and small businesses. Journal of Business Venturing 2(1): 79-93.

Berger, P. L. (1999). The desecularization of the World: Resurgent Religion and World Politics. (William B Eerdmans. Washington, D.C).

Berger, P. L., \& Luckmann, T. 1967. The social construction of reality : a treatise in the sociology of knowledge. London: Penguin.

Bloor, D. (1976). Knowledge and Social Imagery. (London: Routledge \& Kegan Paul).

Cantillon, R. (1755/1931). Essai sur la nature du commerce en général. (Edited and translated by H. Higgs, London: McMillan).

Casson, M. (2003). The Entrepreneur: An Economic Theory. 2d ed. (Cheltenham, U.K.: Edward Elgar).

Chan-Serafin, S. Brief, A. P. and George, J. M. (2013). How Does Religion Matter and Why? Religion and the Organizational Sciences. Organization Science 24(5): 1585-1600.

Chapra, M. U. (1992). Islam and the economic challenge. (Leicester, UK: Islamic Foundation).

Chapra, M. U. (2000). The future of economics: An Islamic perspective. (Leicester, UK: Islamic Foundation).

Dana, L.-P. (2010). Entrepreneurship and Religion. (Cheltenham, U.K.: Edward Elgar).

Dacin, M. T. Dacin, P. A. and Tracey, P. (2011). Social Entrepreneurship: A Critique and Future Directions. Organization Science 22(5): 1203-1213.

DiMaggio, P.J. and Powell, W.W. (1983). The iron cage revisited: Institutional isomorphism and collective rationality in organizational fields. American Sociological Review, 48, $147-160$.

Dodd, S. D. and Gotsis, G. (2007). The interrelationships between religion and entrepreneurship. International Journal of Entrepreneurship and Innovation 8(29): 93 112.

Dodd, S. D. and Seaman, P. (1998). Religion and enterprise: An introductory exploration. Entrepreneurship Theory \& Practice 23(1): 71-77.

Durkheim, E. (1912/1995). Elementary forms of religious life. (New York: Free Press).

El-Ashker, A. A. F. and Wilson, R. (2006). Islamic Economics: A Short History. (Leiden: Brill). 
Essers, C. and Benschop, Y. (2009). Muslim businesswomen doing boundary work: The negotiation of Islam, gender and ethnicity in entrepreneurial contexts. Human Relations, 62(3): 403-423.

Freeman, C. (1995). The "National Systems of Innovation" in historical perspective. Cambridge Journal of Economics 19(1): 5-24.

Friedland, R. and Alford, R.R. (1991). Bringing society back in: Symbols, practices, and institutional contradictions. In W.W. Powell \& P.J. DiMaggio (Eds.), The new institutionalism in organizational analysis, pp. 232-266. (Chicago: University of Chicago Press).

Granovetter, M. (1985). Economic action and social structure: the problem of embeddedness. American Journal of Sociology, 91(3): 481-510.

Greenwood, R., Díaz, A. M., Li, S. X. and Lorente, J. C. (2010). The Multiplicity of Institutional Logics and the Heterogeneity of Organizational Responses. Organization Science, 21(2): 521-539.

Greenwood, R., Raynard, M., Kodeih, F., Micelotta, E. R. and Lounsbury, M. (2011). Institutional Complexity and Organizational Responses. The Academy of Management Annals, 5(1): 317-371.

Greil, A.L. and Davidman, L. (2007). Religion and identity. In J.A. Beckford \& N.J. Demerath, III (Eds.), The Sage handbook of the sociology of religion, pp. 549-565. (London: Sage).

Guemuesay, A.A. (2012). Boundaries and knowledge in a Sufi Dhikr Circle, Journal of Management Development 31(10): 1079-1089.

Gundolf, K. and Filser, M. (2013). Management Research and Religion: A Citation Analysis. Journal of Business Ethics 112(1): 177-185.

Habermas, J. (2001). Glauben und Wissen. (Friedenspreis des Deutschen Buchhandels 2001, Frankfurt a. M.).

Hannan, M.T., and Freeman, J. (1977). The population ecology of organizations. American Journal of Sociology 82(5): 929-964.

Harris, J. D., Sapienza, H. J. and Bowie, N. E. (2009). Ethics and entrepreneurship. Journal of Business Venturing 24(5): 407-418.

Hébert, R. F. and Link, A. N. 1989. In search of the meaning of entrepreneurship. Small Business Economics 1: 39-49.

Jackall, R. (1988). Moral mazes: The world of corporate managers. (Oxford: Oxford University Press). 
Karakas, F. (2010). Spirituality and Performance in Organizations: A Literature Review. Journal of Business Ethics 94(1), 89-106.

Kayed, R. N. and Hassan, K. (2010). Islamic entrepreneurship. (London: Routledge).

Khavul, S. (2010). Microfinance: creating opportunities for the poor? Academy of Management Perspectives 24(3): 58-72.

King Jr., J.E. (2008). (Dis)Missing the Obvious Will Mainstream Management Research Ever Take Religion Seriously? Journal of Management Inquiry, 17(2): 214-224.

Kirzner, I. (1973). Competition and Entrepreneurship. (Chicago: University of Chicago Press).

Kirzner, I. (1979). Perception, Opportunity, and Profit: Studies in the Theory of Entrepreneurship. (Chicago: University of Chicago Press).

Knight, F. (1921). Risk uncertainty and profit. (New York: Houghton-Miffin).

Kuhn, T. S. (1962). The Structure of Scientific Revolutions. (Chicago: University of Chicago Press).

Kuran, T. (1989). On the Notion of Economic Justice in Contemporary Islamic Thought. International Journal of Middle East Studies 21(2): 171-91.

Kuran, T. (1996). The Discontents of Islamic Economic Morality. American Economic Review 86(2): 438-42.

Kuran, T. (2011). The long divergence: how Islamic law held back the Middle East. (Princeton, N.J.: Princeton University Press).

Lundvall, B. A. (ed.) (1992). National Systems of Innovation: towards a theory of innovation and inter-active learning. (London: Pinter).

Maes, J. P. and Reed, L. R. (2012). State of the Microcredit Summit Campaign Report 2012. (Washington, D.C.: Microcredit Summit Campaign).

Mair, J. and Marti, I. (2006). Social Entrepreneurship research: A source of explanation, prediction and delight. Journal of World Business 41(1): 36-44.

Marx, K. (1843/1972). Contribution to the critique of Hegel's philosophy of the right: Introduction. In C. Tucker (Ed.), The Marx-Engels reader, pp. 11-23. (New York: W.W. Norton).

Meyer, J.W. and Rowan, B. (1977). Institutionalized organizations: Formal structure as myth and ceremony. American Journal of Sociology 83(2): 440-463.

Mitroff, I. I. and Denton, E. A. (1999). A study of spirituality in the workplace. Sloan Management Review 40(4): 83-92.

Naqvi, S. N. H. (1994). Islam economics and society. (London: Kegan Paul International). 
Neck, C. P. and Milliman, J. F. (1994). Thought self-leadership, finding spiritual fulfillment in organizational life. Journal of Managerial Psychology 9(6): 9-16.

Nichols, A. (2006). Social Entrepreneurship: New models for sustainable change. Oxford: Oxford University Press.

Oliver, C. (1991). Strategic Responses to Institutional Processes. The Academy of Management Review, 16(1): 145-179.

Pache, A.-C., and Santos, F. (2010). When Worlds Collide: The Internal Dynamics of Organizational Responses to Conflicting Institutional Demands. Academy of Management Review, 35(3): 455-476.

Pew Research Centre (2011). The Future of the Global Muslim Population: Projections for 2010-2030. (Washington, DC: The Pew Research Centre).

Pew Research Centre (2012). The World's Muslims: Unity and Diversity. (Washington, DC: The Pew Research Centre).

Pless, N. M. (2012). Social Entrepreneurship in Theory and Practice - An introduction. Journal of Business Ethics 111(3): 317-320.

Possumah, B.T., Ismail, A.G. and Shahimi, S. (2013). Bringing Work Back in Islamic Ethics. Journal of Business Ethics 112(2) 257-270.

Rahman, Abdul Rahim Abdul, and Abdul Rahim (2007). "Islamic microfinance: a missing component in Islamic banking." Kyoto Bulletin of Islamic Area Studies 1.2: 38-53.

Ramadan, T. (2009). Radical reform: Islamic ethics and liberation. (Oxford: Oxford University Press).

Rice, G. (1999). Islamic Ethics and the Implications for Business. Journal of Business Ethics 18(4) 345-358.

Rinallo, D., Scott, L. and MacLaran, P. (2013). Consumption and Spirituality. (New York: Routledge).

Rodinson, M. (1974). Islam and Capitalism. (London: Allen Lane).

Roomi, M. A. and Harrison, P. (2010). Behind the veil: women-only entrepreneurship training in Pakistan. International Journal of Gender and Entrepreneurship 2(2): 150 - 172.

Roulet, T.J. and Touboul, S. (2014). The Intentions with Which the Road is Paved: Attitudes to Liberalism as Determinants of Greenwashing. Journal of Business Ethics, forthcoming.

Said, E. (1978). Orientalism. (London: Routledge and Kegan Paul).

Siddiqi, M. N. (1981). Muslim Economic Thinking: A Survey of Contemporary Literature in Studies in Islamic Economics. (Leicester: The Islamic Foundation). 
Siddiqi, M. N. (1992). Islamic Economic Thought: Foundations, Evolution and Needed Direction, in AbulHasan M. Sadeq and A. Ghazali (eds.), Readings in Islamic Economic Thought. Kuala Lumpur: Longman Malaysia.

Schneider, M. and Teske, P. (1992). Toward a theory of the political entrepreneur: Evidence from local government. American Political Science Review 86(3): 737-747.

Schumpeter, J. A. (1911/1934). The Theory of Economic Development. (Cambridge, MA: Harvard University Press).

Selznick, P. (1949). TVA and the grass roots: A study in the sociology of formal organization. (Berkeley, CA: University of California Press).

Shapero, A. and Sokol, L. (1982). The Social Dimensions of Entrepreneurship, in Kent, C., Sexton, D., and Vesper, K.H. (eds) The Encyclopedia of Entrepreneurship. (Englewood Cliffs, NJ: Prentice-Hall).

Sloane, P. (1999). Islam, modernity and entrepreneurship among the Malays. (London: Macmillan Press).

Smets, M., Morris, T. and Greenwood, R. (2012). From Practice to Field: A Multilevel Model of Practice-Driven Institutional Change. Academy of Management Journal, 55(4): 877-904.

Steingard, D. S. (2005). Spiritually-informed management theory: Toward profound possibilities for inquiry and transformation. Journal of Management Inquiry, 14(3): 227-241.

Temporal, P. (2011). Islamic Branding and Marketing. (Asia: Wiley).

Thornton, P.H. and Ocasio, W. (1999). Institutional logics and the historical contingency of power in organizations: Executive succession in the higher education publishing industry, 1958-1990. American Journal of Sociology 105(3): 801-843.

Tracey, P. (2012). Religion and Organization: A Critical Review of Current Trends and Future Directions. The Academy of Management Annals, 6(1): 87-134.

Turner, B.S. (1984). Capitalism and class in the Middle East: theories of social change and economic development. (London: Heinemann Educational).

Ul-Haq, S. and Westwood, R. (2012). The politics of knowledge, epistemological occlusion and Islamic management and organization knowledge. Organization 19(2): 229-257.

Usmani, M. T. (2001). An Introduction to Islamic Finance. (The Hague: Kluwer Law International).

Uygur, S. (2009). The Islamic Work Ethic and the Emergence of Turkish SME OwnerManagers. Journal of Business Ethics 88(1):211-225. 
Yousef, D.A. (2001). Islamic Work Ethic: A moderator between organizational commitment and job satisfaction in a cross-cultural context. Personnel Review, 30(2): 152-169.

Ysseldyk, R., Matheson, K. and Anisman, H. (2010). Religiosity as identity: Toward an understanding of religion from a social identity perspective. Personality and Social Psychology Review 14(1): 60-71.

Weber, M. (1904-5/1965). The Protestant ethic and the spirit of capitalism. (London: Allen \& Unwin).

Weick, K. E. (1979). The social psychology of organizing. (Reading, MA: Addison-Wesley).

Weick, K. E. (1993). The Collapse of Sensemaking in Organizations: The Mann Gulch Disaster. Administrative Science Quarterly 38(4): 628-652.

Wempe, J. (2005). Ethical Entrepreneurship and Fair Trade. Journal of Business Ethics 60(39): 211-220.

Williamson, O.E. (1985). The Economic Institutions of Capitalism. (New York: Free Press).

Wilson, R. (2006). Islam and Business. Thunderbird International Business Review 48(1): $109-123$.

Zaher, T. S. and Hassan, K. M. (2001). A Comparative Literature Survey of Islamic Finance and Banking. Financial Markets, Institutions \& Instruments 10(4): 155-199. 